\title{
Biosurfactant Producing Bacteria for Management of Rhizome Rot Caused by Pythium aphanidermatum (Edson) Fitzp. in Turmeric
}

\author{
P.T. Sharavanan ${ }^{1^{*}}$ and K. Nageswari ${ }^{2}$ \\ ${ }^{1}$ Krishi Vigyan Kendra, Tamil Nadu Agricultural University, Vridhachalam- 606001, \\ Cuddalore Dt Tamil Nadu, India \\ ${ }^{2}$ Vegetable Research Station, Tamil Nadu Agricultural University, Palur-607102, Cuddalore \\ Dt, Tamil Nadu, India \\ *Corresponding author
}

\begin{tabular}{|l|}
\hline Ke y w or d s \\
$\begin{array}{l}\text { Pythium } \\
\text { aphanidermatum } \\
\text { (Edson), Turmeric }\end{array}$ \\
\hline Article Info \\
\hline $\begin{array}{l}\text { Accepted: } \\
\text { 12 April } 2018 \\
\text { Available Online: } \\
\text { 10 May } 2018\end{array}$ \\
\hline
\end{tabular}

\section{A B S T R A C T}

Bacteria producing biosurfactant molecules is beneficial to manage rhizome rot of turmeric caused by Pythium spp. A detailed study was conducted on biosurfactant producing bacteria for management of rhizome rot of turmeric. Initially, a survey was conducted to find out the incidence of the disease in turmeric growing of areas of Tamil Nadu, it was observed that rhizome rot in turmeric was also ranged from 9.16 to 71.55 and the maximum incidence was noticed in Ammampalayam (71.55\%). Rhizome rot affected turmeric plants were collected from various places of Tamil Nadu and used for isolation of Pythium pathogen. The bacteria were isolated from fresh roots of turmeric collected from various places of turmeric. The isolated pure culture were sent to Microbial Type Culture Collection, Institute of Microbial Technology, Chandigarh for further identification and identified as Bacillus tequilensis, Pseudomonas koreensis, and P. monteilii. Among them, P. tequilensis performed better in reducing the mycelial growth of Pythium isolates $(1.18 \mathrm{~cm})$ and which is followed by $P$. monteilii $(1.19 \mathrm{~cm})$. While screening of surfactant ability, $B$. tequilensis produced halo line at a distance of $1.5 \mathrm{~cm}$ in basal salt medium and 1.11 $\mathrm{cm}$ in Siegmund and Wagner medium amended with CTAB. Under pot culture condition, increased plant height $(73.24 \mathrm{~cm})$ was observed from Bacillus tequilensis when challenge inoculation with Pythium pathogen in turmeric rhizome after six month. In order to develop a bioremediation method for rhizome rot of turmeric, field trials were conducted for assessing the performance of the bacteria in the field condition against the disease and the rhizome treated with $0.2 \%$ Bacillus tequilensis for $20 \mathrm{~min}+$ Soil application of B. tequilensis at $2.5 \mathrm{~kg} / \mathrm{ha}$ at 3,5 and $7 \mathrm{MAS}$ was performed better in reducing the rhizome rot diseases incidence in turmeric $(13.34 \%$ at Dharmapuri and $11.67 \%$ at Gobichettipalayam). The same treatment also showed increased level of yield of rhizome over control and the yield was recorded in turmeric is 12.85 tonne/acre at Dharmapuri and 12.67 t/acre at Gobichettipalayam. 


\section{Introduction}

Turmeric (Curcuma longa L.) is Land of spices and the yield of the crop affected by rhizome rot, leaf spot, leaf blotch and leaf blight (Joshi and Sharma, 1980). Among the various diseases, rhizome rot disease caused by Pythium aphanidermatum (Edson) Fitzp. is the most destructive disease in turmeric and drastically reduced its commercial value (Ushamalini et al., 2008) and major disease in all growing areas of turmeric (Rathiah, 1982 and Nagesshwara Rao, 1994). The farmers are frequently using huge chemicals for the control of the disease. However, fungicides have shown promising results in controlling the rhizome rot disease, phytotoxicity and fungicide residues are major problems leading to environmental pollution and human health hazards. Biocontrol approaches help to develop an ecofriendly sustainable management strategy for controlling the diseases. Development of biological control for diseases is accepted as a viable and ecofriendly alternative for agrochemicals. Nowadays, the use of biosurfactants is a promising alternative in biological control of zoospore-producing oomycetes, which are a major plant pathogen world-wide in a wide variety of crops (Hultberg et al., 2010). Biosurfactants are another group of secondary metabolites produced by some Pseudomonas spp and they are polymers of low molecular weight that reduce the surface and interfacial tensions and polymers of high molecular weight that bind to the surfaces (Ron and Rosenberg, 2001). Some of these compounds have antimicrobial activity, like rhamnolipids (RHLs) and peptide biosurfactants. The RHLs showed activity against zoospores of oomycetes. They caused the immobility and lyse of zoospores in less than one minute (Stanghellini and Miller, 1997). Hence, study was undertaken to isolate surfactant producing strain of bacteria for the management of rhizome rot of turmeric.

\section{Materials and Methods}

A detailed survey was conducted to find out the incidence of rhizome rot diseases of Salem, Namakkal, Erode and Dharmapuri district of Tamil Nadu where turmeric is growing as a main crop. Initially, roving survey was conducted by moving into the turmeric growing area and then field was selected randomly as fixed plot survey. In that field, the infected rhizomes were also collected from the field simultaneously.

\section{Isolation of Pythium pathogen}

Rhizome rot affected turmeric plants were collected from various places of Tamil Nadu. The rhizome showing rotting symptoms of the disease were washed in sterile water and cut into small piece using a sterilized scalpel and the pieces were surface sterilized in 0.1 per cent mercuric chloride solution for $30 \mathrm{sec}$ followed by washing in several changes of sterile distilled water.

The Sterile Petri plate was poured with $\mathrm{P}_{10} \mathrm{VP}$ Medium (Difco corn meal agar $17 \mathrm{~g} / \mathrm{L}$, Pimaricin $10 \mathrm{ppm}(=10 \mu \mathrm{g} / \mathrm{ml}$ or $10 \mathrm{mg} / \mathrm{L}$, Vancomycin HCL 200 ppm, Pentachloronitrobenzene (PCNB) $100 \mathrm{ppm}$ ) at $15 \mathrm{ml}$ petri plate $^{-1}$ and the surface sterilized rhizome pieces were placed at 3 pieces plate ${ }^{-1}$ at equidistance. All these were carried out in aseptic condition. The plates were incubated at $28^{\circ} \mathrm{C}$ temperature for five days under darkness, observed for the presence of Pythium and purified by single spore isolation technique by transferring a single spore to PDA medium. Then the well-grown fungal culture was used for this study.

\section{Isolation of bacteria}

The bacteria were isolated from fresh roots of turmeric collected various places turmeric. After vigorous hand shaking of excised roots 
to remove all but slightly adhering soil, root segments $(1 \mathrm{~g})$ were shaken in $100 \mathrm{ml}$ of sterile distilled water for $15 \mathrm{~min}$. One $\mathrm{ml}$ of the suspension was poured into a sterilized Petri plate and $15 \mathrm{ml}$ of sterilized $\mathrm{S} 1$ medium (Gould et al., 1985). The plates were incubated at $28^{\circ} \mathrm{C}$ for $36 \mathrm{~h}$. After incubation, the colonies of plant growth promoting rhizobacteria were identified and pure cultured. The isolated bacteria were sent to Microbial Type Culture Collection, Institute of Microbial Technology, Chandigarh for further identification. Besides, the cultures of Bacillus subtilis and Pseudomonas fluorescens Pf1 strain were also used as check in the study.

\section{Screening of bacteria for surfactant production}

The isolated cultures of bacteria was taken in the Petri plate separately containing basal salt and Siegmund Wagner medium amended with Cetyl Tri Ammonium Bromide (CTAB) Methylene blue agar plates prepared by adding $0.2 \mathrm{~g}$ of CTAB, $0.005 \mathrm{~g}$ methylene blue.

The plates were incubated at $30^{\circ} \mathrm{C}$ for four days. The surfactant molecules production by the bacteria was assessed by observing dark blue halo around the culture. The distance from centre of the culture was measured.

\section{Bioefficacy of strains of bacteria on Pythium pathogen}

Pure cultures of the Pythium spp were initially grown in Petri dishes containing standard PDA $(20 \%$ potato extract, $2 \%$ dextrose and $1.5 \%$ agar) medium and incubated at $28^{\circ} \mathrm{C}$ for 5 days under darkness. After this period, $8 \mathrm{~mm}$ disks were cut from the edge of actively growing colonies of each fungus with the aid of a cork borer. One disc was placed at one side of each dish. Each bacteria isolate was streaked on the other side of the PDA plate at the time of fungi transplanting. After incubation for 2 to 5 days at room temperature, the fungal growth was measured and expressed as per cent inhibition of growth by bacteria.

\section{Effect of isolated bacteria on promotion of growth of turmeric in vivo}

The rhizomes of turmeric were treated with cultures of bacteria and planted in pot and observed after 30 days. Then, the growth of seedlings were measured and compared with control.

The pot with or turmeric (after 30 days of sowing) drenched with $10 \mathrm{ml}$ of culture of Pythium pathogen and $10 \mathrm{ml}$ of culture of the bacteria. After 10 days, the population of Pythium pathogen was assessed and compared with pathogen alone inoculated control.

\section{Development of bioremediation using surfactant producing bacteria against rhizome rot disease of turmeric}

Based on the study, the isolated bacteria viz., Bacillus tequilensis, Pseudomonas koreensis and $P$. monteilii were selected to study their effect in the field condition on rhizome rot incidence in the crops. For large scale application, the talc formulations of the cultures were prepared for field trial. For field application, Talc-based formulation of the bacteria were prepared by the method described by Vidhyasekaran and Muthamilan (1995) and mass multiplied in talc powder. At time of application, the population of bacteria in the formulations was $10^{8} \mathrm{cfu} / \mathrm{g}$ of talc powder.

In order to study the effect of isolated surfactant producing bacteria against rhizome rot diseases of turmeric and its yield, the field trials were conducted in turmeric growing areas of Tamil Nadu. In the field trials, rhizome treatment at $0.2 \%$ of the bacteria for 
$20 \mathrm{~min}$ and soil application of the talc formulation of the bacteria at $2.5 \mathrm{~kg} / \mathrm{ha}$ at 3,5 and 7 month after sowing (MAS) were taken to study their effect so as to develop bioremediation against rhizome rot diseases of turmeric. The rhizome rot incidence was recorded periodically and the yield of the crop was also recorded.

\section{Results and Discussion}

Initially, an elaborate survey was conducted to find out the incidence of rhizome rot of turmeric. The results were presented in Table 1. The turmeric growing areas like Salem, Namakkal and Erode districts were selected and surveyed.

During the survey, it was observed that rhizome rot in turmeric was also ranged from 9.16 to 71.55 and the maximum incidence was noticed in Ammampalayam (71.55\%). During the survey, rhizosphere soil samples from turmeric crops were collected and used for isolation of bacteria under in vitro condition.

There were three strains of bacteria were isolated and named as BCA 1 to BCA 3 . The purified cultures were sent for further identification to Institute of Microbial Technology, Chandigarh and they identified as Bacillus tequilensis, Pseudomonas koreensis and P. monteilii.

\section{Efficacy of isolated bacteria on Pythium pathogen}

The efficacy of isolated bacteria was assessed against isolated strain of Pythium pathogen in vitro. Dual culture plate technique was employed for assessing the efficacy and the results were presented in Table 2. The results revealed that all bacteria had shown inhibitory action on the growth of Pythium and reduce the mycelial weight of Pythium pathogen significantly. Among the bacteria, $P$. tequilensis was performed better in reducing the growth $(1.18 \mathrm{~cm})$ of the pathogen and this is statistically on par with P. monteilii (1.19 $\mathrm{cm})$.

\section{Surfactant production of the bacteria}

The surfactant production ability of the bacteria was assessed and the results were presented in Table 3. The results revealed that all strains of bacteria were produced halo in the basal medium and Siegmund and Wagner medium amended with CTAB and methylene blue. The halo line was observed around the culture growth and $B$. tequilensis and $P$. koreensis produced halo line in a maximum distance level from the centre of the culture. $B$. tequilensis produced halo line at a distance of $1.5 \mathrm{~cm}$ in basal salt medium and $1.11 \mathrm{~cm}$ in Siegmund and Wagner medium. Similarly, the check $B$. subtilis and Pf1 of $P$. fluorescens also produced halo line in the media amended with CTAB.

\section{Effect of isolated bacteria on promotion of growth of ginger and turmeric under in vivo condition}

The isolated bacteria was used for study their effect on growth of turmeric in pot culture condition. The results were presented in Table 4 and the results revealed that both Bacillus tequilensis + Pythium pathogen inoculated turmeric plants have increased plant height $(73.24 \mathrm{~cm})$ when challenge inoculation. However, B.tequilensis alone showed increased plant height $(76.25 \mathrm{~cm})$. This study implies that $B$. tequilensis or other bacteria in the study given protection to the turmeric even in pathogen present in the rhizosphere. The population of Pythium and incidence of rhizome rot were observed in the soil when challenge inoculated with the Pythium. Pythium alone inoculated turmeric plants exhibited 28.34 per cent of rhizome rot incidence. 
Table.1 Occurrence of rhizome rot disease incidence in turmeric

\begin{tabular}{|c|c|c|c|c|c|}
\hline $\begin{array}{l}\text { Sl. } \\
\text { No }\end{array}$ & Name of the Place & $\begin{array}{l}\text { Name of the } \\
\text { Block }\end{array}$ & $\begin{array}{l}\text { Stage of the } \\
\text { crop }\end{array}$ & $\begin{array}{l}\text { No of } \\
\text { fields } \\
\text { visited }\end{array}$ & $\begin{array}{l}\text { Per cent } \\
\text { incidence of } \\
\text { rhizome rot }\end{array}$ \\
\hline 1 & Aragalur & Thalaivazal & Maturity stage & 5 & $17.33(24.59)$ \\
\hline 2 & Kondhampadi & Thalaivazal & Maturity stage & 5 & $18.63(25.57)$ \\
\hline 3 & Ammampalayam & Attur & Maturity stage & 6 & $71.55(57.76)$ \\
\hline 4 & Ammampalayam (S) & Attur & Maturity stage & 4 & $9.16(17.56)$ \\
\hline 5 & Deviakurichi & Attur & Maturity stage & 3 & $15.32(23.03)$ \\
\hline 6 & Deviakurichi & Attur & Maturity stage & 5 & $20.58(26.97)$ \\
\hline 7 & Essampatti & Malliyakarai & Maturity stage & 5 & $21.83(27.85)$ \\
\hline 8 & Podinaickanpatti & Malliyakarai & Maturity stage & 5 & $7.58(15.98)$ \\
\hline 9 & Sivathapuram & Elampillai & Maturity stage & 5 & $25.08(30.05)$ \\
\hline 10 & Nangavalli & Nangavalli & Maturity stage & 6 & $18.23(25.27)$ \\
\hline 11 & Kulimedu & Senthamangalam & Maturity stage & 4 & $17.34(24.61)$ \\
\hline 12 & Mullukurichi & Rasipuram & Maturity stage & 3 & $17.25(24.54)$ \\
\hline 13 & Velagoundampalayam & P. Velur & Maturity stage & 4 & $18.75(25.65)$ \\
\hline 14 & Paramathy & P. Velur & Maturity stage & 4 & $19.25(26.02)$ \\
\hline \multirow[t]{3}{*}{15} & Semmedu & Kolli hills & Maturity stage & 3 & $42.33(40.59)$ \\
\hline & $\mathrm{CV}$ & -- & -- & & 2.39 \\
\hline & CD at $0.05 \%$ & -- & - & & 1.19 \\
\hline
\end{tabular}

The value in parenthesis are are sine transformed values.

Table.2 Effect of bacteria on the growth of Pythium pathogen in vitro

\begin{tabular}{|r|l|c|c|}
$\begin{array}{c}\text { Sl. } \\
\text { No }\end{array}$ & Strains of the bacteria & $\begin{array}{c}\text { *Mycelial growth of } \\
\text { Pythium }\end{array}$ & $\begin{array}{c}\text { Per cent reduction of } \\
\text { pycelial growth over control }\end{array}$ \\
\hline 1 & Bacillus tequilensis & 1.18 & $\mathbf{8 4 . 3 1}$ \\
\hline 2 & Pseudomonas koreensis & 1.19 & $\mathbf{7 8 . 7 6}$ \\
\hline 3 & P. monteilii & 1.54 & $\mathbf{8 4 . 6 4}$ \\
\hline 4 & Bacillus subtilis (check) & 1.20 & $\mathbf{8 4 . 3 1}$ \\
\hline 5 & $\begin{array}{l}\text { Pf1 strain of } \text { P. fluorescens } \\
\text { (check) }\end{array}$ & 1.51 & 79.74 \\
\hline 6 & Control & 7.53 & -- \\
\hline & CV & 2.79 & \\
\hline
\end{tabular}

* Mean of four replications 
Table.3 Surfactant line produced by isolated bacteria in the medium amended with CTAB and methylene blue

\begin{tabular}{|c|c|c|c|}
\hline \multirow[t]{2}{*}{$\begin{array}{l}\text { Sl. } \\
\text { No }\end{array}$} & \multirow[t]{2}{*}{ Strains of the PGPR } & \multicolumn{2}{|c|}{$\begin{array}{l}\text { *Distance of Surfactant line produced from the } \\
\text { centre }(\mathrm{cm})\end{array}$} \\
\hline & & Basal salt Medium & $\begin{array}{l}\text { Siegmund - Wagner } \\
\text { medium }\end{array}$ \\
\hline 1 & Bacillus tequilensis & 1.5 & 1.11 \\
\hline 2 & Pseudomonas koreensis & 1.28 & 0.82 \\
\hline 3 & P. monteilii & 0.33 & 0.39 \\
\hline 4 & Bacillus subtilis (Check) & 0.70 & 0.72 \\
\hline 5 & Pf1 of P. fluorescens (Check) & 0.65 & 0.43 \\
\hline \multirow[t]{3}{*}{6} & Control & NE & $\mathbf{N E}$ \\
\hline & $\mathrm{CV}$ & 6.89 & 8.64 \\
\hline & CD at $0.05 \%$ level & 0.116 & 0.113 \\
\hline
\end{tabular}

NE: Not expressed

* Mean of four replications

Table.4 Effect of isolated bacteria on promotion of growth of turmeric under in vivo condition

\begin{tabular}{|c|c|c|c|c|}
\hline $\begin{array}{l}\text { Sl. } \\
\text { No }\end{array}$ & Bacteria & $\begin{array}{l}\text { Plant height of } \\
\text { turmeric }(\mathrm{cm}) *\end{array}$ & $\begin{array}{l}\text { Population of } \\
\text { Pythium pathogen } \\
\left(x 10^{6} \mathrm{cfu} / \mathrm{g} \text { of soil)* }\right.\end{array}$ & $\begin{array}{l}\text { Per cent rhizome } \\
\text { rot incidence* }\end{array}$ \\
\hline 1 & Bacillus tequilensis & 76.25 & 0.0 & 0.0 \\
\hline 2 & Pseudomonas koreensis & 72.41 & 0.0 & 0.0 \\
\hline 3 & P. monteilii & 73.62 & 0.0 & 0.0 \\
\hline 4 & $\begin{array}{l}\text { B. tequilensis }+ \text { Pythium } \\
\text { pathogen }\end{array}$ & 72.41 & 1.42 & 6.04 \\
\hline 5 & $\begin{array}{l}\text { P. koreensis + Pythium } \\
\text { pathogen }\end{array}$ & 73.24 & 2.04 & 8.52 \\
\hline$\overline{6}$ & $\begin{array}{l}\text { P. monteilii + Pythium } \\
\text { pathogen }\end{array}$ & 70.14 & 2.75 & 12.24 \\
\hline 7 & Pythium alone & 68.25 & 10.24 & 28.34 \\
\hline \multirow[t]{3}{*}{8} & Uninoculated control & 0.0 & 0.0 & 0.0 \\
\hline & $\mathrm{CV}$ & 2.17 & 4.51 & 2.01 \\
\hline & $\mathrm{CD}$ at $0.05 \%$ level & 1.04 & 0.45 & 0.063 \\
\hline
\end{tabular}

* Mean of four replications, Each replication contain ten pots containing two plants/pot. The data were recorded six month after rhizome planting in pot. 
Table.5 Effect of isolated bacteria on incidence of rhizome rot of turmeric

\begin{tabular}{|c|c|c|c|c|c|}
\hline \multirow[t]{2}{*}{$\begin{array}{l}\text { S } \\
\text { No }\end{array}$} & \multirow[t]{2}{*}{ Treatment } & \multicolumn{2}{|c|}{$\begin{array}{l}\text { *Rhizome rot incidence in turmeric } \\
(\%)\end{array}$} & \multicolumn{2}{|c|}{ *Yield of rhizome in turmeric (t/acre) } \\
\hline & & $\begin{array}{l}\text { At Dharmapuri } \\
\text { (Variety: Attur } \\
\text { local) }\end{array}$ & $\begin{array}{l}\text { At } \\
\text { Gobichettipalayam } \\
\text { (Variety: BSR 1) }\end{array}$ & $\begin{array}{l}\text { At Dharmapuri } \\
\text { (Variety: Attur } \\
\text { local) }\end{array}$ & $\begin{array}{l}\text { At } \\
\text { Gobichettipalayam } \\
\text { (Variety: BSR 1) }\end{array}$ \\
\hline T1 & $\begin{array}{l}\text { Rhizome treated with } 0.2 \% \text { Bacillus } \\
\text { tequilensis for } 20 \mathrm{~min}+\text { Soil application of } B \text {. } \\
\text { tequilensis at } 2.5 \mathrm{~kg} / \mathrm{ha} \text { at } 3,5 \text { and } 7 \mathrm{MAS}\end{array}$ & $13.34(21.42)$ & $11.67(19.97)$ & 12.85 & 12.67 \\
\hline T3 & $\begin{array}{l}\text { Rhizome treated with } 0.2 \% P . \text { monteilii for } \\
20 \text { min }+ \text { Soil application of P. monteilii at } 2.5 \\
\mathrm{~kg} / \mathrm{ha} \text { at } 3,5 \text { and } 7 \text { MAS }\end{array}$ & $16.72(24.12)$ & $14.72(22.56)$ & 10.42 & 11.23 \\
\hline T5 & $\begin{array}{l}\text { Rhizome treated with } 0.2 \% \text { B. subtilis } \\
\text { (check) for } 20 \mathrm{~min}+\text { Soil application of Pf1 } \\
\text { strain of B. subtilis (check) at } 2.5 \mathrm{~kg} / \mathrm{ha} \text { at } 3,5 \\
\text { and } 7 \text { MAS }\end{array}$ & $17.93(25.04)$ & $17.27(24.55)$ & 12.03 & 11.23 \\
\hline T6 & $\begin{array}{l}\text { Chemical- } 0.25 \% \text { Copper oxy chloride } \\
\text { drench when the disease incidence noticed }\end{array}$ & $15.67(23.27)$ & $15.16(22.90)$ & 11.87 & 12.43 \\
\hline \multirow[t]{3}{*}{$\mathrm{T7}$} & Control & $25.92(30.59)$ & $22.16(28.08)$ & 10.20 & 9.87 \\
\hline & $\mathrm{CV}$ & 4.79 & 3.03 & 3.12 & 3.71 \\
\hline & $\mathrm{CD}$ at $0.05 \%$ level & 2.07 & 1.25 & 0.57 & 0.75 \\
\hline
\end{tabular}

* Mean of three replications. The rhizome rot recorded at 8 and 9 month after planting in the field. The value in parenthesis are sine transformed values. 
Effect of isolated bacteria on incidence of rhizome rot of turmeric

In order to develop a bioremediation method for rhizome rot of ginger and turmeric, field trials were conducted for assessing the performance of the bacteria in the field condition against the disease. The trial was laid at Dharmapuri and Gobichettipalayam areas and there were seven treatments were imposed in the trial. The results were presented in Table 5 and it was found that rhizome treated with $0.2 \%$ Bacillus tequilensis for $20 \mathrm{~min}+$ Soil application of $B$. tequilensis at $2.5 \mathrm{~kg} / \mathrm{ha}$ at 3,5 and 7 MAS was performed better in reducing the rhizome rot diseases incidence in turmeric $(13.34 \%$ at Dharmapuri and $11.67 \%$ at Gobichettipalayam). The same treatment also showed increased level of yield of rhizome over control and the yield was recorded in turmeric is 12.85 tonne/acre at Dharmapuri and 12.67 tonne/acre at Gobichettipalayam. In the field trial, chemical application acts as superior in control of rhizome rot disease and increased yield in turmeric and ginger crop. The data were presented in the table shows that $0.25 \%$ Copper oxychloride drench drench had recorded more yield of $10.20 \mathrm{t} / \mathrm{ha}$ and $9.87 \mathrm{t} / \mathrm{ha}$ in the two locations viz., Dharmapuri and Gobichettipalayam respectively.

The results of the present investigation indicated the potential of bacteria from rhizosphere region in suppressing rhizome rot of turmeric. The disease suppression may be through direct or indirect interaction. The performance of Pseudomonas spp against Pythium sp. has been proved by many workers (Bhai et al., 2005., Ongena et al., 1999; Vogt and Buchenauer 1997). In this study, three bacterial isolates were obtained from the rhozosphere of turmeric crops and all the isolates are proved for production of surfactant molecules when it grown in media amended with CTAB. Isolated bacteria viz., Bacillus tequilensis, Pseudomonas koreensis and $P$. monteilii already proven as biosurfactant by Hultberg et al., 2009

Microbial compounds that alter the conditions prevailing at a surface or interface are often referred to as adjuvants, bioemulsifiers, or biosurfactants (Cooper and Zajic, 1980; Fiechter, 1992).

Pseudomonas spp. are common inhabitants of soil and rhizosphere environments and have received considerable attention in recent years in the areas of bioremediation of biological control of plant-pathogenic fungi (de Souza $e t$ al., 2003). Recent studies shown that biosurfactant producing Pseudomonas spp are very effective in controlling the disease caused by Oomycte pathogens including Pythium and Phytopthora (Stanghellini et al., 1996; Stanghellini and Miller, 1997; De Jonghe 2006; Nielson et al., 2006). Cyclic lipopeptide surfactant molecule present in Pseudomonas koreensis is responsible for the suppression of Pythium ultimum in tomato (Hultberg et al., 2009). Pseudomonas aeruginosa producing Rhamnolipids were effective against plant pathogens viz., Pythium aphanidermatum, Plasmopara lactucae-radicis and Phytophthora capsici (Stanghellini and Miller, 1997).

Similarly, the antagonistic bacteria including B. tequilensis were found to be very effective against Fusarium oxysporum f. sp. gerberae both under in-vitro and protected cultivation conditions with plant growth promoting activities as it comprised the AMP producing genes (Suneeta et al., 2016). Pradhan et al., (2013) explained halophilic nature of surfactant molecule produced from B. tequilensis inhibited the growth of microorganism. Earlier, $P$. chlororaphis (PcPA23) and B. subtilis (BsCBE4) were found effective in inhibition of mycelial 
growth of Pythium aphanidermatum, reducing rhizome rot incidence in turmeric both under greenhouse and field conditions and increased the plant growth and rhizome yield (Kavitha et al., 2012).

Hence, the results of our studies clearly shown that surfactant molecule producing Bacillus tequilensis and Pseudomonas koreensis are effectively controls Pythium rhizome rot in turmeric and confirmed by observing reduction of rhizome rot incidence in field trials.

\section{Acknowledgments}

The authors are grateful to the Science and Engineering Research Board, Department of Science and Technology, New Delhi for financial support under fast track scheme to carry out the research works.

\section{References}

Bhai, R. S., Kishore, V. K., Kumar,A., Anandaraj, M., and Eapen. S. J. 2005. Screening of rhizobacterial isolates against soft rot disease of ginger (Zingiber officinale Rosc.). Journal of Spices and Aromatic Crops, 14 (2): 130-136.

Cooper, D.G., and Zajic, J. E. 1980. Surfaceactive compounds from microorganisms. Adv. Appl. Microbiol., 26: 229-253

De Jonghe, H. 2006. Control of Phytopthora spp. By means of Biosurfactants and surfactant producing Pseudomonas spp. Ph.D Thesis, Universiteit Gent, 182p

De Souza, T.J., Marjan de Boer, Pieter de Waard, Teris A., van Beek and Raaijmakers, J.M. 2003. Biochemical, Genetic and Zoosporicidal Properties of Cyclic Lipopeptide Surfactants Produced by Pseudomonas fluorescens.

\section{Applied and Environmental Microbiology, 69: 161-7172}

Fiechter, A. 1992. Biosurfactants: moving towards industrial application. Trends Biotechnol., 10: 208-217.

Hultberg, M. T., Alsberg, S., Khalil, Alsanius, B. 2010. Suppression of disease in tomato infected by Pythium ultimum with a biosurfactant produced by Pseudomonas koreensis. Biocontrol, 55: 435-444

Joshi, L.K. and Sharma, N.D. 1980. Diseases of Ginger and Turmeric. In: Nair, M.K., Premkumar, T., Ravindran, P.N., and Sarma, Y.R. (Eds.), Proc. Nat. Sem. Ginger Turmeric, Calicut, April 8-9, 1980. CPCRI, Kasaragod, pp. 104-119.

Kavitha, K., Nakeeran, S. and Chandrasekar, G. 2012. Rhizobacterial-mediated induction of defense enzymes to enhance the resistance of turmeric (Curcuma longa $\mathrm{L}$ ) to Pythium aphanidermatum causing rhizome rot. Archives of Phytopathology and Plant Protection, 45: 199-219

Nageshwara Rao T. G.1994. Turmeric rhizome rot and its management. Spice India, 7: 17-19.

Nielson, C.J., Ferrin, D.M., Stanghellini, M.E. 2006. Efficicay of biosurfactants in the management of Phytopthora capsici on pepper in recirculating hydroponic systems. Canadian Journal of Plant Pathology- Revue Canadienne De phytopathologie, 28: 480-460

Ongena, M., Daayf, F., Jacques, P., Thonart, P., Benhamou, N., Paulitz, T. C., Cornelis, P., Kedam, N., and Belanger, R. R. 1999. Protection of cucumber against Pythium root rot by fluorescent pseudomonads: Predominant role of induced resistance over siderophores and antibiosis. Plant Pathology, 48: 6676.

Pradhan, A.K., Pradhan, N., Mall, G., Panda, H.T., Sukla, L.B., Panda, P.K. and 
Mishra, B.K. 2013. Application of lipopeptide biosurfactant isolated from a halophile: Bacillus tequilensis $\mathrm{CH}$ for inhibition of biofilm. Applied biochemistry and biotechnology, 171(6): 1362-1375

Rathiah Y. 1982. Rhizome rot of turmeric. Indian Phytopathology, 35: 415-417

Ron, E.Z. and Rosenberg, E. 2001. Natural roles of biosurfactants. Environ Microbiol., 3(4):229-36.

Stanghellini, M.E. and Miller, R.M. 1997. Their identity and potential efficacy in the biological control of zoosporic plant pathogens. Plant Dis., 81: 4-12

Stanghellini, M.E., Kim, D.H., and Rasmussen, Sl., Rorabaugh, PA. 1996. Control of root rot of pepper caused by Phytopthora capsici with a nonioninc surfactant. Plant Dis., 80: 1113-1116

Suneeta, P., Eraivan, A. A. K., Nakkeeran, S. 2016. Investigations on Antifungal activity of Bacillus spp. against Fusarium oxysporum f. sp. gerberae (FOG) causing Wilt of Gerbera under Protected Cultivation. J. Pure and Applied Microbiol., 10 (3): 2099-2111.
Ushamalini, C., Nakkeeran, P. and Marimuthu, T. 2008. Induction of plant defense enzymes in turmeric plants by Trichoderma viride. Archives of. Phytopathology and Plant Protection, 41: 79-93.

Vidhyasekaran, P. and Muthamilan, M. 1995. Development of formulations of Pseudomonas fluorescens for control of chickpea wilt. Plant Dis., 79: 782-786.

Vogt, W., and Buchenauer, H. 1997. Enhancement of biological control of combination of antagonistic fluorescent Pseudomonas strains and resistance inducers against damping off and powdery mildew in cucumber. $Z$. Pflanzenkrankheiten Pflanzenschutz, 104: 272-280.

Gould*, W.D., C. Hagedorn, T. R. Bardinelli and R. M. Zablotowicz. 1985. New Selective Media for Enumeration and Recovery of Fluorescent Pseudomonads from Various Habitats. Appl. Environ. Microbiol., 49 (1): 28-32

\section{How to cite this article:}

Sharavanan, P.T. and Nageswari, K. 2018. Biosurfactant Producing Bacteria for Management of Rhizome Rot Caused by Pythium aphanidermatum (Edson) Fitzp. in Turmeric. Int.J.Curr.Microbiol.App.Sci. 7(05): 1421-1430. doi: https://doi.org/10.20546/ijcmas.2018.705.169 